\title{
STUDI BEBERAPA FAKTOR PENDUKUNG PENGEMBANGAN EKOWISATA BERBASIS FAUNA ENDEMIK DI HUTAN SAWINGGRAI KECAMATAN MIOSMANSAR KABUPATEN KEPULAUAN RAJA AMPAT PROPINSI PAPAUA BARAT
}

\author{
Michael Yeblo*, H. J. Kiroh**) M. J. Nangoy**) V. R. W. Rawung**) \\ Fakultas Peternakan Universitas Sam Ratulangi Manado, 95115
}

\begin{abstract}
ABSTRAK
Ekowisata merupakan wisata alam yang berfokus di suatu wilayah atau daerah konservasi (Protected area ) yang memberi kontribusi bagi kesejahteraan masyarakat lokal dan konservasi serta pendidikan bagi masyarakat. Kepulauan Raja Ampat merupakan daerah yang sangat berpotensi untuk dijadikan objek wisata, Hutan sawinggrai adalah salah satu hutan yang memiliki potensi ekowisata yang cukup baik untuk dikembangkan, dimana hutan ini memiliki keunikan dengan hewan hewan endemik diantaranya kantung semar (Nepenthes sp), Damar (Agathis sp), Kumbang biru (Eulophis geoffroyi), Cendrawasih Merah (Paradiseaea Rumbra), dan beragam hewan lainnya.

Penelitian ini bertujuan untuk mengetahui faktor-faktor pendukung pengembangan ekowisata berbasis fauna endemik di hutan sawinggrai di Desa Kapisawar, Sawinggrai, Yenwapnor, Kecamatan Miosmansar Kabupaten Raja Ampat. Penelitian tentang studi beberapa faktor pendukung pengembangan ekowisata hutan sawinggrai, telah dilaksanakan pada tanggal 11 Oktober sampai dengan tanggal 18 November 2014 bertempat di Desa Kapisawar, Sawinggrai, Yenwapnor, Kecamatan Miosmansar Kabupaten Raja Ampat yang letaknya dekat dengan hutan sawinggrai. Yang menjadi objek dalam penelitian ini adalah fauna endemik di Raja Ampat. Peralatan yang digunakan dalam penelitian ini
\end{abstract}

\footnotetext{
* Alumni Fakultas Peternakan

** Jurusan Produksi Ternak
}

adalah Kamera Digital, ATM (Alat Tulis Menulis), komputer untuk mengolah data, Quisioner dalam bentuk daftar pertanyaan yang berkaitan dengan respons masyarakat terhadap pengembangan ekowisata berbasis fauna endemik. Penelitian ini menggunakan survey serta wawancara secara langsung dengan masyarakat. Variabel yang diamati adalah: 1). Tingkat pendidikan, 2). Pekerjaan masyarakat, 3). Flora dan Fauna endemik, 4). Respons masyarakat terhadap pengembangan ekowisata, 5). Gangguan masyarakat terhadap fauna langkah endemik dan, 6). Peran instansi yang terkait. Berdasarkan hasil analisa data dan pembahasan untuk semua variabel pada penelitian ini, maka dapat disimpulkan bahwa beberapa faktor pendukung pengembangan ekowisata berbasis fauna endemik hutan sawinggrai cukup baik dan hutan sawinggrai dikatakan layak untuk dijadikan tempat ekowisata.

Kata kunci: ekowisata, fauna endemik, faktor pendukung, pendidikan masyarakat

\section{ABSTRACT}

\begin{tabular}{llr} 
THE STUDY OF & SUPPORTING \\
FACTORS THE & ECOTOURISM \\
DEVELOPMENT & OF & ENDEMIC \\
FAUNA IN & THE & FOREST \\
SAWINGGRAI, & & DISTRICT \\
\multicolumn{2}{l}{ MIOSMANSAR, RAJA AMPAT, PAPUA }
\end{tabular}

BARAT. Ecotourism is nature tourism that focuses on an area or areas of conservation (Protected area) that contribute to the welfare of local communities and 
conservation and education for the community. Raja Ampat Islands is an area that has the potential to be used as attractions, Sawinggrai Forest is one of the forest that has the potential of ecotourism is good enough to be developed, which is unique in the forest with animals including endemic animal bag Semar (Nepenthes sp), Resin (Agathis sp), Blue Beetle (Eulophis geoffroyi), Red Bird of Paradise (Paradiseaea Rumbra), and a variety of other animals.

This study aims to determine the factors supporting the development of ecotourism endemic fauna in the forest in the village Sawinggrai Kapisawar, Sawinggrai, Yenwapnor, District Miosmansar Raja Ampat. Research on the study of several contributing factors Sawinggrai forest ecotourism development, was held on October 11 until the date of 18 November 2014 took place in the village of Kapisawar, Sawinggrai, Yenwapnor, District Miosmansar Raja Ampat which is located near the forest Sawinggrai. Which is the object of this research is endemic fauna in Raja Ampat. The equipment used in this study is Digital Cameras, ATM (Stationery Writing), a computer to process data, questionnaires in the form of a list of questions related to the community's response to the endemic fauna-based ecotourism development. This study uses a survey and interviews directly with the public. The variables measured were: 1). Level of education, 2). Community work, 3). Flora and fauna endemic, 4). Community response to the development of ecotourism, 5). Public disturbance to fauna endemic step and, 6). Based on the results of the data analysis and discussion for all variables in this study, it can be concluded that some of the factors supporting the development of forest-based ecotourism endemic fauna and forest Sawinggrai good enough Sawinggrai is feasible to be a place of ecotourism.
Keywords: ecotourism, endemic fauna, supporting factor, public education

\section{PENDAHULUAN}

Ekowisata sebagai penyelenggaraan kegiatan wisata yang bertanggung jawab di tempat-tempat alami dan atau daerahdaerah yang dibuat berdasarkan kaidah alam dan secara ekonomi berkelanjutan yang mendukung upaya-upaya pelestarian lingkungan (alam dan budaya) dan meningkatnkan kesejahtraan masyarakat setempat. Kabupaten Raja Ampat adalah salah satu kabupaten yang berada di Propinsi Papua barat yang terletak di daerah kepulauan sehingga kabupaten ini disebut sebagai kabupaten kepulauan Raja Ampat. Kepulauan Raja Ampat merupakan daerah yang sangat berpotensi untuk dijadikan objek wisata, terutama wisata bahari (penyelaman). Hutan sawinggrai adalah salah satu hutan yang memiliki potensi ekowisata yang cukup baik untuk dikembangkan, dimana hutan ini memiliki keunikan dengan hewan - hewan endemik diantaranya kantung semar (Nepenthes $s p$ ), Damar (Agathis sp), Kumbang biru (Eulophis geoffroyi), Cendrawasih Merah (Paradiseaea Rumbra), dan beragam hewan lainnya.

Wisata adalah kegiatan perjalanan yang dilakukan dari suatu tempat ke tempat lain 
dengan suatu maksud dan dilakukan dalam jangka waktu tertentu (Fenell, 1990). Sedangkan Kelly (1998) menyatakan bahwa klasifikasi bentuk wisata yang dikembangkan berdasarkan pada bentuk utama atraksi atau daya tariknya yang kemudian ditekankan pada pemasarannya. Bentuk wisata tersebut antara lain berupa: ekowisata (ecoturism), wisata alam (nature tourism), wisata petualangan (adventure tourism) dan wisata budaya (cultural tourism). Menurut Gunn (1994), suatu kawasan dikembangkan untuk tujuan wisata karena terdapat atraksi yang merupakan komponen dari suplai. Kawasan wisata tergantung pada sumberdaya alami dan budaya, dimana distribusi dan kualitas dari sumberdaya ini dengan kuat mendorong pengembangan wisata. Meningkatkan kepedulian terhadap sumberdaya alam secara universal menyebabkan timbulnya bentuk kegiatan wisata yang berbasis pada alam. Salah satu bentuk wisata alam tersebut adalah ekowisata atau ecotourism. Menparda (2002) menyatakan kegiatan ekowisata dapat didefinisikan sebagai penggunaan daerah alam oleh pengunjung berjumlah kecil yang memiliki kemampuan dan pengetahuan dengan tujuan untuk mempelajari suatu pengalaman baru.
Sedangkan menurut Fandeli (2000), ekowisata diberi batasan sebagai kegiatan yang bertumpu pada lingkungan dan bermanfaat secara ekologis, sosial ekonomi bagi masyarakat serta kelestarian sumberdaya berkelanjutan. Habitat adalah kawasan yang terdiri dari berbagai komponen fisik yang merupakan satu kesatuan untuk dipergunakan sebagai tempat mencari makan, minum dan bermain serta berkembang biak. Habitat bukan saja tempat tinggal tetapi juga sebagai tempat perlindungan dari segala macam gangguan dalam hal menyediakan makanan, tempat berkembang biak dan tempat memelihara anak (Smith, 1998). Biodiversitas (keanakaragaman hayati) ialah keanekaragaman diantara mahluk hidup dari semua sumber termasuk diantaranya daratan, lautan dan ekosistem aquatik lainnya yang mencakup keanekaragaman didalam spesies, diantara spesies dan ekosistem (Menparda, 2002). Menurut Alikodra (1990), bahwa akibat kurangnya kesadaran dari masyarakat mengakibatkan kerusakan ekosistem dalam jangka waktu yang tidak terlalu lama dapat mengancam keberadaan hidup flora dan fauna karena dengan kondisi demikian maka penyebab menurunnya populasi satwa tidak dapat dihindari lagi. 


\section{MATERI DAN METODE PENELITIAN}

Penelitian ini telah dilaksanakan pada tanggal 11 Oktober sampai dengan tanggal 18 November 2014 bertempat di Desa Kapisawar, Sawinggrai, Yenwapnor, Kecamatan Miosmansar Kabupaten Raja Ampat yang letaknya dekat dengan hutan sawinggrai. Yang menjadi objek dalam penelitian ini adalah fauna endemik di Raja Ampat. Peralatan yang digunakan dalam penelitian ini adalah Kamera Digital, ATM (Alat Tulis Menulis), komputer untuk mengolah data, Quisioner dalam bentuk daftar pertanyaan yang berkaitan dengan respons masyarakat terhadap pengembangan ekowisata berbasis fauna endemik.

Metode yang digunakan dalam penelitian ini adalah survey, serta melakukan wawancara secara langsung dengan masyarakat yang ada disekitar Hutan Sawinggrai. Variabel yang diamati adalah: 1). Tingkat pendidikan, 2). Pekerjaan masyarakat, 3). Flora dan Fauna endemik, 4). Respons masyarakat terhadap pengembangan ekowisata, 5). Gangguan masyarakat terhadap fauna langkah endemik dan, 6). Peran instansi yang terkait.

Metode Pengumpulan Data berlangsung dalam 3 tahap, yaitu:
1. Orientasi Lapangan

Sebelum penelitian/pengambilan data di lapangan maka terlebih dahulu dilakukan orientasi lapangan selama 1 minggu untuk mengetahui situasi serta keadaan lapangan terutama masyarakat yang akan dijadikan responden yang benar-benar bermukim di Desa sekitar Hutan Sawinggrai. Orientasi lapangan dilakukan dengan tujuan untuk mempermudah dalam penentuan desa-desa yang berjarak 500 meter dekat wilayah pengembangan ekowisata.

\section{Pengumpulan Data}

Data dikumpulkan dengan cara mendatangi langsung responden dan mewawancarai dengan pertanyaanpertanyaan yang telah di persiapkan sebelumnya dalam bentuk quisioner.

\section{Analisis Data}

Data/informasi yang diperoleh ditab ulasi dan dianalisis dengan menghitung presentasi dari tiap-tiap variabel yang terkait dengan pengembangan ekowisata berbasis fauna endemik di Hutan Sawinggrai.

\section{HASIL DAN PEMBAHASAN}

Hutan Sawinggrai berada di Pulau Gam yang secara topografi merupakan dataran pulau yang mempunyai bentuk pantai landai. Secara geografis 
pulau Gam berbatasan dengan pulau Waisay dibagian barat, bagian utara berbatasan dengan pulau Waigeo, bagian timur berbatasan langsung dengan pulau Manswar, dan bagian selatan berbatasan dengan pulau Fam dan gak.

\section{Tingkat Pendidikan Masyarakat Disekitar Hutan Sawinggrai.}

Pendidikan masyarakat merupakan salah satu faktor yang ikut mempengaruhi tingkat pemahaman terhadap pengembangan ekowisata berbasis fauna endemik yang ada di hutan Sawinggrai. Hasil yang di peroleh dari masyarakat (responden) yang berada di sekitar Hutan Sawinggrai Desa Kapisawar, Sawinggrai, Yenwapnor, Kecamatan Miosmansar, Kabupaten Raja Ampat menunjukkan bahwa pendidikan masyarakat di sekitar
Hutan Sawinggrai sangat bervariasi untuk lebih jelasnya dapat dilihat pada Tabel 1 dibawah ini.

Dari data di atas, terlihat bahwa jumlah masyarakat (responden) yang mencapai Sekolah Dasar, Desa Sawinggrai memiliki jumlah lebih banyak yaitu $50 \%$ dibandingkan dengan Desa Yenwapnor dan Kapisawar yang terendah $36 \%$ dan $28 \%$. Sedangkan untuk tingkat pendidikan SMP didapatkan di Desa Sawinggrai terendah dengan persentase $18 \%$ dan tertinggi berada di Desa Yenwapnor dengan persentase $32 \%$. Masyarakat (responden) yang melanjutkan pendidikan ke tingkat SMU didapatkan terendah dengan persentase $32 \%$, berada pada Desa Sawinggrai dan Yenwapnor dan untuk pendidikan tingkat sarjana Desa Kapisawar ditemukan 2\%. Dari hasil tersebut

\section{Tabel 1. Persentase Tingkat Pendidikan Masyarakat (Responden) Di Sekitar Hutan} Sawinggrai.

\begin{tabular}{lcccc}
\hline & \multicolumn{3}{c}{ Tingkat Pendidikan } \\
Desa & SD & SMP & SMU & PT \\
\hline \multirow{3}{*}{ Kapisawar } & 14 & 13 & 22 & 1 \\
& $(28 \%)$ & $(26 \%)$ & $(44 \%)$ & $(2 \%)$ \\
Sawinggrai & 25 & 9 & 16 & 0 \\
& $(50 \%)$ & $(18 \%)$ & $(32 \%)$ & $(0 \%)$ \\
Yenwapnor & 18 & 16 & 16 & 0 \\
& $(36 \%)$ & $(32 \%)$ & $(32 \%)$ & $(0 \%)$ \\
\hline
\end{tabular}

Keterangan : Nilai dalam kurung adalah persentase masing-masing tingkat pendidikan. 
dihubungkan dengan hasil wawancara peneliti dengan kepala Desa Kapisawar, mengatakan bahwa di desa Kapisawar dan Sawinggrai hanya terdapat satu sekolah dasar yang berada di Desa Kapisawar (SD YPK Ilim Sawinggrai Kapisawar) begitupula dengan SMP. Anak-anak yang melanjutkan pendidikan ke tingkat SMP maka mereka harus melanjutkan di ibu kota Kecamatan Miosmansar, dan begitu pula dengan SMA yang harus ke ibu kota Kabupaten Waisay atau ke Kabupaten Sorong.

Gambaran pendidikan masyarakat ini menunjukkan bahwa semakin tinggi tingkat pendidikan seseorang, maka mereka akan lebih cepat dalam menerima suatu informasi baru, maka dengan sendirinya jika upaya perlindungan terhadap Flora dan Fauna terus dikembangkan maka mereka juga aktif ikut berperan dalam memberikan dampak kepada masyarakat yang berpendidikan rendah. Disamping itu pendidikan juga merupakan salah satu cara penunjang dalam pembangunan diberbagai sektor termasuk didalamnya sektor industri pariwisata. Soekartawi dkk, (2001) mengatakan bahwa pada umumnya pendidikan dari seseorang akan mempengaruhi cara berpikir sehingga dalam bekerja mereka akan memperhitungkan pekerjaan yang menguntungkan dan yang merugikan mereka serta pendidikan tentunya dapat diperoleh dari pendidikan formal dan informal. Dengan pendidikan juga tentunya masyarakan lokal yang ada disekitar areal wisata akan dapat dimaksimalkan untuk berpartisipasi dalam proses pengambilan keputusan berkaitan dengan pengelolaan kawasan ekowisata.

\section{Mata Pencaharian Masyarakat.}

Mata pencaharian merupakan suatu usaha untuk memenuhi kebutuhan hidup (ekonomi) dengan cara bekerja. Mata pencaharian masyarakat berbeda satu sama lain, perbedaan itu diantaranya dapat disebabkan oleh keadaan geografis, sosial, maupun corak budaya masyarakat disamping kemampuan (skill) yang dimiliki. Faktor-faktor tersebut sangat berpengaruh terhadap corak mata pencaharian suatu masyarakat. Misalnya masyarakat yang tinggal di daerah dataran tinggi umumnya bermata pencaharian sebagai petani. Hal ini disebabkan karena wilayah dataran tinggi cocok untuk pertanian yang ditunjang oleh pasokan air yang memadai serta suhu yang mendukung bagi pertumbuhan tanaman. Berbeda halnya dengan masyarakat yang tinggal di wilayah dataran rendah, umumnya jarang ditemui masyarakat yang bermata pencaharian sebagai petani karena tidak ditunjang oleh pasokan air serta suhu 
Tabel 2. Persentase Mata Pencaharian Masyarakat (Responden) Disekitar Hutan Sawinggrai Kecamatan Miosmansar

\begin{tabular}{|c|c|c|c|c|c|c|c|}
\hline \multirow{2}{*}{ Desa } & \multicolumn{7}{|c|}{ Mata Pencaharian } \\
\hline & PNS & Swasta & $\begin{array}{c}\text { TNI/ } \\
\text { POLRI }\end{array}$ & Tani & Nelayan & Tukang & Lainnya \\
\hline Kapisawar & $\begin{array}{c}3 \\
(6 \%)\end{array}$ & $\begin{array}{c}1 \\
(2 \%)\end{array}$ & $\begin{array}{c}0 \\
(0 \%)\end{array}$ & $\begin{array}{c}12 \\
(24 \%)\end{array}$ & $\begin{array}{c}22 \\
(44 \%)\end{array}$ & $\begin{array}{l}4 \\
(8 \%)\end{array}$ & $\begin{array}{c}8 \\
(16 \%)\end{array}$ \\
\hline Sawinggrai & $\begin{array}{c}2 \\
(4 \%)\end{array}$ & $\begin{array}{c}0 \\
(0 \%)\end{array}$ & $\begin{array}{c}0 \\
(0 \%)\end{array}$ & $\begin{array}{c}8 \\
(16 \%)\end{array}$ & $\begin{array}{c}29 \\
(58 \%)\end{array}$ & $\begin{array}{c}2 \\
(4 \%)\end{array}$ & $\begin{array}{c}9 \\
(18 \%)\end{array}$ \\
\hline Yenwapnor & $\begin{array}{c}4 \\
(8 \%)\end{array}$ & $\begin{array}{c}0 \\
(0 \%)\end{array}$ & $\begin{array}{c}0 \\
(0 \%)\end{array}$ & $\begin{array}{c}5 \\
(10 \%)\end{array}$ & $\begin{array}{c}24 \\
(48 \%)\end{array}$ & $\begin{array}{c}1 \\
(2 \%)\end{array}$ & $\begin{array}{c}16 \\
(32 \%)\end{array}$ \\
\hline
\end{tabular}

Keterangan : Nilai didalam kurung adalah persentase dari mata pencaharian di tiap-tiap desa.

yang memadai. Berbeda lagi dengan masyarakat yang tinggal di daerah pantai, umumnya mereka bermata pencaharian sebagai nelayan. Mata pencarian masyarakat yang ada disekitar hutan Sawinggrai, tentunya sangat berpengaruh terhadap kehidupan mereka. Hasil penelitian yang diperoleh dari masyarakat menunjukkan bahwa masih ada masyarakat yang berada disekitar hutan Sawinggrai sering melakukan aktivitas di hutan guna kebutuhan keluarga mereka. Untuk lebih jelas tentang mata pencaharian masyarakat yang ada di sekitar hutan Sawinggrai pada tabel 2 di bawah ini.

Berdasarkan hasil penelitian yang diperoleh dari masyarakat (responden) tentang mata pencaharian masyarakat yang ada disekitar hutan Sawinggrai menunjukkan bahwa masyarakat Desa Kapisawar, Sawinggrai, dan Yenwapnor umumnya merupakan masyarakat yang banyak mata pencahariannya sebagai nelayan dibandingkan dengan yang lain misalnya dilihat dari hasil penelitian di atas menunjukkan bahwa Pegawai Negeri Sipil (PNS) terendah 4\% di dapatkan pada Desa Sawinggrai dan tertinggi (8\%), berada di Desa Yenwapnor, sedangkan Pegawai Swasta di Desa Kapisawar 2\% dan di dua Desa Sawinggrai dan Yenwapnor ditemukan (0\%). Begitupula dengan masyarakat (responden) yang berprofesi sebagai TNI/POLRI didapatkan pada Desa sekitar hutan Sawinggrai yang dijadikan tempat penelitian adalah $(0 \%)$. Berbeda dengan masyarakat (responden) yang mata pencahariannya sebagai petani yang berdasarkan hasil, ternyata masyarakat (responden) yang ada di sekitar hutan Sawinggrai yang mata 
pencahariannya sebagai petani adalah $(10 \% \quad-\quad 24 \%)$. Sedangkan untuk masyarakat (responden) yang mata pencahariannya sebagai nelayan ditemukan tertinggi di Desa Sawinggrai dengan persentase (58\%) dibandingkan dengan Desa Kapisawar dan Yenwapnor dimana Desa kapisawar dengan persentase terendah (44\%). Selain mata pencaharian di atas didapatkan juga pekerjaan lain yang di miliki masyarakat (responden) di sekitar hutan Sawinggrai dengan persentase (16\% - 32\%) yang adalah sebagai Tukang, Pegawai honorer, Pelajar, dan juga Ibu rumah tangga. Berdasarkan Jenis pekerjaan yang diperoleh masyarakat (responden) yang ada disekitar hutan Sawinggrai dan juga letak geografis yang mendukung, maka diharapkan kepada Pemerintah Propinsi Papua Barat dan terlebih khusus untuk Pemerintah Kabupaten Raja Ampat sebagai hak pengambilan keputusan ditingkat kabupaten agar bisa memberikan sumbangsih berupa alat pancing dan juga pasar untuk menjual hasil tangkapan mereka. Maka dengan demikian usaha pengembangan dan pelestarian flora dan fauna yang diupayahkan oleh pemerintah Kabupaten Raja Ampat bisa berjalan dengan baik.

Menurut (Fennell dan Eagles, 1990) bahwa dengan hadirnya ekowisata yang merupakan wisata alam yang berfokus di suatu wilayah tertentu atau daerah konservasi (protected areas) maka kegiatan tersebut harus mampu memberikan kontribusi bagi kesejahteraan masyarakat lokal dan konservasi serta pendidikan bagi masyarakat.

\section{Fauna Endemik Yang Pernah Dilihat Dan Yang Tidak Pernah Dilihat Oleh Masyarakat di Hutan Sawinggrai.}

Fauna endemik hutan sawinggrai (pulau Gam) memiliki keunikan yang mempunyai potensi untuk dikembangkan. Dengan adanya keunikan flora dan fauna semacam ini maka akan merupakan salah satu faktor pendukung yang dimanfaatkan untuk menunjang kegiatan ekowisata di Kabupaten Raja Ampat. Menurut Lindberg (2002) bahwa potensi ekowisata dapat dikelompokkan ke dalam dua bagian yaitu potensi yang berkaitan dengan sumberdaya alam (SDA) yang menjadi objek dan subjek wisata dan respon yang baik dari PEMDA, sektor swasta dan masyarakat lokal untuk mengembangkan kegiatan ekowisata satwa endemik. Daerah kepulauan Kabupaten Raja Ampat sangat baik untuk dijadikan daerah ekowisata karena didukung dengan hewan- hewan yang sangat khas seperti burung Cendrawasih, Nuri, Kakatua, Kus-kus dan 
Tabel 3. Jenis Fauna Dan Flora Yang Pernah Dan Tidak Dilihat Oleh Masyarakat) Responden Di Hutan Sawinggrai.

\begin{tabular}{|c|c|c|c|c|c|c|}
\hline Desa & $\begin{array}{l}\text { Pernah } \\
\text { Melihat }\end{array}$ & $\begin{array}{l}\text { Tidak } \\
\text { Pernah } \\
\text { Melihat }\end{array}$ & \multicolumn{2}{|c|}{$\begin{array}{l}\text { Jenis Fauna } \\
\text { Yang Dilihat }\end{array}$} & \multicolumn{2}{|c|}{$\begin{array}{l}\text { Flora } \\
\text { Yang Penah } \\
\text { Dilihat }\end{array}$} \\
\hline Kapisawar & $\begin{array}{c}50 \\
(100 \%)\end{array}$ & $\begin{array}{c}0 \\
(0 \%)\end{array}$ & $\begin{array}{l}\text { - Nuri } \\
\text { - Kakatua } \\
\text { - Ular kuning } \\
\text { - Jangkrik } \\
\text { - Tupai }\end{array}$ & $\begin{array}{l}16(32 \%) \\
14(28 \%) \\
5(10 \%) \\
8(16 \%) \\
7(14 \%)\end{array}$ & $\begin{array}{l}\text { - Merbau } \\
\text { - Nato } \\
\text { - Susu } \\
\text { - Tikar } \\
\text { - Rotan }\end{array}$ & $\begin{array}{l}11(22 \%) \\
14(28 \%) \\
3(6 \%) \\
17(34 \%) \\
5(10 \%)\end{array}$ \\
\hline Sawinggrai & $\begin{array}{l}50 \\
(100 \%)\end{array}$ & $\begin{array}{c}0 \\
(0 \%)\end{array}$ & $\begin{array}{l}\text { - Cendrawasih } \\
\text { - Maleo } \\
\text { - Kus-kus } \\
\text { - Mambruk } \\
\text { - Rangkong }\end{array}$ & $\begin{array}{c}15(30 \%) \\
12(24 \%) \\
8(16 \%) \\
10(20 \%) \\
5(10 \%)\end{array}$ & $\begin{array}{l}\text { - Anggrek } \\
\text { - Matoa } \\
\text { - Lansat } \\
\text { - Pinang } \\
\text { - Genemo }\end{array}$ & $\begin{array}{l}16(32 \%) \\
8(16 \%) \\
5(10 \%) \\
14(28 \%) \\
7(14 \%)\end{array}$ \\
\hline Yenwapnor & $\begin{array}{l}50 \\
(100 \%)\end{array}$ & $\begin{array}{c}0 \\
(0 \%)\end{array}$ & $\begin{array}{l}\text { - Kum-kum } \\
\text { - Kelelawar } \\
\text { - Babi Hutan } \\
\text { - Elang } \\
\text { - Kupu-kupu }\end{array}$ & $\begin{array}{l}13(26 \%) \\
8(16 \%) \\
11(22 \%) \\
10(20 \%) \\
8(16 \%)\end{array}$ & $\begin{array}{l}\text { - Beringin } \\
\text { - Ketapan } \\
\text { - Jambu h } \\
\text { - Kemiri } \\
\text { - Sukun }\end{array}$ & $\begin{array}{c}19(38 \%) \\
5(10 \%) \\
\tan 6(12 \%) \\
11(22 \%) \\
9(18 \%)\end{array}$ \\
\hline
\end{tabular}

$\overline{\text { Keterangan : Nilai di dalam kurung adalah persentase melihat dan tidak melihat satwa di }}$ hutan Sawinggrai.

lain-lain. Untuk mengetahui masyarakat yang tinggal di sekitar hutan Sawinggrai yang mana pernah melihat satwa-satwa khas tersebut maka dapat dilihat pada Tabel 3.

Dari hasil penelitian diatas menunjukkan bahwa masyarakat yang bermukim di sekitar hutan Sawinggrai yaitu Desa Kapisawar, Sawinggrai, dan Yenwapnor rata-rata pernah melihat satwa (fauna) endemik, dimana hasil penelitian menunjukkan bahwa besarnya persentase masyarakat (responden) yang pernah melihat satwa endemik yaitu rata-rata $100 \%$, sedangkan persentase masyarakat (responden) yang ada di sekitar hutan Sawinggrai yang tidak pernah melihat hewan endemik adalah $0 \%$ dengan alasan karena masyarakat- masyarakat (responden) ini tempat tinggalnya sangat dekat dengan hutan dan selalu hidup berdampingan dengan hutan.

Berdasarkan data yang diperoleh dari penelitian ini tentunya peluang untuk pengembangan fauna endemik untuk dijadikan ekowisata di hutan sawinggrai sangat baik untuk dikembangkan. Karena menurut Kreb (2010), bahwa pemilihan satwa endemik atau lokal sebagai objek 
utama kegiatan ekowisata mempunyai beberapa tujuan yang dapat dikelompokkan ke dalam tiga bagian yaitu : tujuan ekologi, pendidikan dan sosialekonomi. Tujuan pertama berkaitan dengan aspek ekologi khususnya kesinambungan kehidupan liar endemik.

\section{Respons Masyarakat Terhadap Pengembangan Ekowisata berbasis Fauna Endemik Di Hutan Sawinggrai.}

Usaha pengembangan ekowisata sangat menguntungkan tidak hanya bagai pelaku bisnis, dan Pemerintah tetapi juga bagi penduduk setempat dan lingkungannya. Dengan konsep ini maka harus menimalkan dampak negatif dari mass tourism dari segi lingkungan, budaya, dan sosial. Ekowisata memiliki tujuan edukatif yang menyebarkan pesan konservasi dan pemahaman mengenai daerah yang dikunjungi.

Berdasarkan hasil penelitian bahwa hutan Sawinggrai memiliki berbagai fauna endemik dan flora khas, fauna edemik ini bisa dikembangkan dan dipasarkan keseluruh dunia karena memiliki keunikan tersendiri namun dibutuhkan dukungan dan respon dari masyarakat setempat terhadap upaya pemerintah dalam mengembangkan fauna endemik dengan menjadikan daerah ekowisata.

Untuk mengetahui persentase masyarakat yang memahami dan setuju bila hutan sawinggrai dijadikan pusat pengembangan ekowisata berbasis fauna endemik maka dapat dilihat pada Tabel 4.

Tabel 4. Persentase Respons Masyarakat (Responden) Terhadap Pengembangan Ekowisata Berbasis Fauna Endemik Di Hutan Sawinggrai.

\begin{tabular}{ccccc}
\hline \multirow{2}{*}{ Desa } & \multicolumn{3}{c}{ Respons Masyarakat } \\
\cline { 2 - 5 } & $\begin{array}{l}\text { Mengerti } \\
\text { Ekowisata }\end{array}$ & $\begin{array}{c}\text { Tidak } \\
\text { Mengerti } \\
\text { Ekowisata }\end{array}$ & $\begin{array}{l}\text { Setuju } \\
\text { Dikembangkan } \\
\text { Ekowisata }\end{array}$ & $\begin{array}{l}\text { Tidak setuju } \\
\text { Dikembangkan } \\
\text { Ekowisata }\end{array}$ \\
\hline Kapisawar & 35 & 15 & 38 & 12 \\
Sawinggrai & $(70 \%)$ & $(30 \%)$ & $(76 \%)$ & $(24 \%)$ \\
& 40 & 10 & 44 & $(12 \%)$ \\
Yenwapnor & $(80 \%)$ & $(20 \%)$ & $(88 \%)$ & 15 \\
& & & & $35 \%$ \\
\end{tabular}

Keterangan: Nilai dalam kurung adalah persentase untuk masing-masing desa yang setuju dan yang tidak setuju 
Dari tabel 4 menunjukkan bahwa persentas e respons masyarakat terhadap pengemban gan ekowisata fauna endemik di hutan sawinggrai sangat berbeda - beda. Tetapi pada prinsipnya masyarakat (responedn) sangat mendukung dan setuju dimana persentasenya $70 \%-88 \%$ dan masyarakat (responden) yang mengerti tentang ekowisata fauna endemik adalah $70 \%-80 \%$.

Data diatas menunjukkan bahwa di Desa Kapisawar, Sawinggrai, dan Yenwapnor yang adalah berdekatan dengan hutan Sawinggrai dimana mereka sudah cukup mengerti dan ikut menunjang program pemerintah dalam upaya pelestarian fauna endemik yang ada di Kabupaten Raja Ampat, bila hutan sawinggrai terus di kembangkan dan diperhatikan serius oleh Pemerintah untuk dijadikan lokasi ekowisata.

Pemerintah harus mempunyai inisiatif dan dapat secara mandiri mengembangkan potensi pariwisata termasuk ekowisata berbasis fauna endemik, karena Pemerintah daerah mempunyai kewenangan untuk merencanakan, melaksanakan dan megelola kegiatan ekowisata untuk kesejahteraan masyarat dan secara tidak langsung dapat meningkatkan PAD. Adanya kewenangan daerah yang sesuai dengan kebijakan dan peraturan daerah membuat pemerintah daerah perlu mengelolah potensi ekowisata secara mandiri termasuk pengembangan kelembagaan dalam pengembangan ekowisata ditingkat daerah

( Memparda, 2000).

Dilihat dari data diatas tentang setuju atau tidak setujunya masyarakat, dimana hutan Sawinggrai dijadikan lokasi pengembangan ekowisata fauna edemik, sesuai dengan data di atas maka ada sebagian masyarakat (responden) yang ada di Desa sekitar hutan sawinggrai yaitu Desa Kapisawar, Sawinggrai, dan Yenwapnor yang kurang setuju 12\% - 30\% jika hutan sawingrai dijadikan lokasi pengembangan ekowisata fauna endemik, dengan alasan bahwa mereka akan sulit untuk mencari kayu bakar dan berkebun untuk mencukupi kebutuhan mereka.

\section{Gangguan Masyarakat Terhadap Fauna Endemik Di Lokasi Hutan Sawinggrai}

Sesuai Undang-Undang konservasi bahwa hewan-hewan langka endemik yang hampir punah harus dilindungi dimana masyarakat tidak diberi kesempatan untuk menangkap atau memeliharanya, dengan adanya undang-undang di atas maka Burung Cendrawasih Merah (Paradisaea Rubra) salah satu hewan endemik yang ada di hutan Sawinggrai yang harus di lindungi. Hutan Sawinggrai banyak menyimpan kekayaan hayati flora/fauna 
Tabel 5. Persentasi Masyarakat (Responden) Yang Mengetahui Adanya Kegiatan Yang Mengganggu Fauna Di Hutan.

\begin{tabular}{lcccc}
\hline & \multicolumn{4}{c}{ Aktivitas masyarakat di dihutan sawinggrai } \\
\cline { 2 - 4 } Desa & $\begin{array}{c}\text { Mengetahui } \\
\text { Ada Aktivitas }\end{array}$ & $\begin{array}{c}\text { Tidak Mengetahui } \\
\text { Ada Aktivitas }\end{array}$ & $\begin{array}{c}\text { Mengetahui } \\
\text { Perburuan Satwa Liar }\end{array}$ & $\begin{array}{c}\text { Tidak Mengetahui } \\
\text { Perburuan Satw Liar }\end{array}$ \\
\hline \multirow{2}{*}{ Kapisawar } & 15 & 35 & 6 & 44 \\
& $(30 \%)$ & $(70 \%)$ & $(12 \%)$ & $(88 \%)$ \\
Sawinggrai & 24 & 26 & 12 & 38 \\
& $(48 \%)$ & $(52 \%)$ & $(24 \%)$ & $(76 \%)$ \\
Yenwapnor & 27 & 23 & 8 & 42 \\
& $(54 \%)$ & $(46 \%)$ & $(16 \%)$ & $(84 \%)$ \\
\hline Keterangan
\end{tabular}

Keterangan : Nilai di dalam kurung adalah persentase untuk masing-masing desa yang mengetahui adanya aktivitas serta mengetahui dan tidak mengetahui adanya perburuan satwa liar.

endemik yang tinggi dan memiliki nilai ekonomis bila terus dilindungi dan dikembangkan sebagai kegiatan wisata alam dengan tampilan hewan-hewan khas daerah dimana selama ini sudah mulai nampak dikembangkan secara alami di hutan tersebut contohnya penarian Burung Cendrawasi Merah yang telah menarik perhatian dari sebagian wisatawan yang datang berwisata ke Raja Ampat. Dari hasil penelitian menunjukkan bahwa masih ada sebagian kecil masyarakat di disekitar hutan Sawingrai di Desa Kapisawar, Sawinggrai, dan Yenwapnor yang melakukan aktivitas di hutan. Untuk mengetahui lebih jauh berapa besarnya persentase masyarakat (responden) yang mengetahui adanya kegiatan-kegiatan masyarakat seperti berkebun atau penangkapan satwa liar misalnya babi hutan, burung Maleo, Kum-kum, Nuri dapat dilihat pada Tabel 5 .

Tabel 5, menunjukkan bahwa besarnya nilai persentase masyarakat (responden) yang mengetahui adanya kegiatan masyarakat di hutan Sawinggrai sangat bervariasi untuk Desa Kapisawar, Sawinggrai, dan Yenwapnor adalah 30\% - 54\%. Sedangkan masyarakat (responden) yang tidak mengetahui adanya aktivitas di hutan sawinggrai mencapai nilai persentase antara $46 \%$ - 70\%. Aktivitas masyarakat di hutan sawinggrai adalah untuk mencukupkan kebutuhan keluarga mereka.

Data di atas menunjukkan bahwa masih ada sebagian masyarakat disekitar hutan sawinggrai yang ada di Desa Kapisawar, Sawinggrai, dan Yenwapnor pernah melakukan penangkapan/perburuan satwa liar khususnya untuk babi hutan 
terutama pada saat hari raya atau acara lainnya. Hal ini dilakukan untuk memenuhi kebutuhan konsusmsi pada acara tersebut. Sekitar $12 \%-24 \%$ masyarakat (responden) yang melihat adanya perburuan terhadap satwa liar, sedangkan masyarakat (responden) yang berada disekitar hutan sawinggrai yang tidak melihat dan mengetahui adanya perburuan satwa liar yang dilindungi mencapai persentase $76 \%-88 \%$.

Hasil ini menunjukkan bahwa jika ada upaya perlindungan dari berbagai pihak baik Pemerintah yang terkait, akademisi, LSM dan masyarakat maka upaya pelestarian satwa liar endemik yang dilindungi akan berjalan dengan baik.

\section{Peran Instansi Terkait Dalam}

Konsevasi Sumber Daya Alam Di Hutan Sawinggrai.

Hutan sawinggrai perupakan salah satu dari hutan yang berada dikabupaten Raja Ampat, hutan ini memiliki keaneka ragaman hayati yang harus menjadi perhatian dari pemerintah setempat. Hasil wawancara dengan masyarakat yang ada disekitar hutan Sawinggrai, Desa Kapisawar, Sawinggrai, dan Yenwapnor mengindikasikan bahwa hanya sedikit sekali peran yang telah ditunjukkan oleh pemerintah dalam hal ini instansi yang terkait.

Tabel 6. Persentase Masyarakat (Responden) Yang Mengetahui Peran Instansi Terkait Dalam Konservasi Fauna Endemik Di Hutan Sawinggrai.

\begin{tabular}{lcccc}
\hline \multirow{2}{*}{ Desa } & \multicolumn{4}{c}{ Peran Instansi Terkait } \\
\cline { 2 - 5 } & $\begin{array}{l}\text { Tidak } \\
\text { Mengetahui } \\
\text { Ada Petugas } \\
\text { KSDA }\end{array}$ & $\begin{array}{l}\text { Mengetahui } \\
\text { Ada Petugas } \\
\text { KSDA }\end{array}$ & $\begin{array}{c}\text { Ada } \\
\text { Penyuluhan }\end{array}$ & $\begin{array}{c}\text { Tidak Ada } \\
\text { Penyuluhan }\end{array}$ \\
\hline \multirow{2}{*}{ Kapisawar } & 6 & 44 & 6 & 0 \\
& $(12 \%)$ & $(88 \%)$ & $(12 \%)$ & $(0 \%)$ \\
& 10 & 40 & 9 & 1 \\
Sawinggrai & $(20 \%)$ & $(80 \%)$ & $(18 \%)$ & $(2 \%)$ \\
& 2 & 48 & 2 & 0 \\
Yenwapnor & $(4 \%)$ & $(96 \%)$ & $(4 \%)$ & $(0 \%)$ \\
\hline
\end{tabular}

Keterangan: Nilai dalam kurung adalah persentase masyarakat (responden) yang mengetahui adanya petugas KSDA dan yang tidak mengetahui serta petugas yang melaksanakan prnyuluhan. 
Dari tabel 6 dapat dilihat persentase masyarakat (responden) yang bermukim disekitar hutan Sawinggrai seperti Desa Kapisawar, Sawinggrai, dan Yenwapnor yang mengetahui adanya petugas KSDA cukup bervariasi antara $4 \%-20 \%$. Hal ini menunjukkan bahwa masih kurang efektif, Instansi terkait memberikan pemahaman kepada masyarakat yang ada di sekitar hutan Sawinggrai tentang pentingnya Konservasi Sumberdaya Flora dan Fauna yang ada.

Diketahui bahwa sedikit sekali masy arakat (responden) di Desa Kapisawar, Sa winggrai, dan Yenwapnor yang mengetahui adanya petugas KSDA dari dinas kehutanan dan kurang berfungsinya secara efektif unit-unit terkait dalam rangka memberi pamahaman pada masyarakat tentang pentingnya konservasi hewan-hewan langka endemik yang dilindungi di hutan Sawinggrai. Hasil penelitian juga menunjukkan bahwa besarnya nilai persentase dari masyarakat disekitar hutan Sawinggrai yang tidak mengetahui adanya petugas KSDA dan dinas Kehutanan cukup tinggi dan bervariasi yaitu $80 \%-96 \%$. Gambaran ini menunjukkan kinerja dan sosialisasi petugas KSDA ke masyarakat yang ada disekitar hutan Sawinggrai belum begitu baik dalam memberikan penyuluan tentang konservasi.
Perlu ada kerja sama antara masyarakat dan pemerintah guna melindungi dan mengembangkan potensi daerah dalam hal ini satwa liar endemik yang ada supaya tetap terjaga dan terhindar dari kepunaan. Dari kurang lebih 15 spesies satwa endemik yang pernah dilihat oleh masyarakat di wilayah pengembangan ekowisata berbasis fauna endemik di Desa Kapisawar, Sawinggrai, dan Yenwapnor maka yang paling menonjol populasinya adalah burung Cendrawasih merah (Paradisaea rubra).

Burung Cendrawasih atau yang disebut dalam bahasa asing Bird of Paradisaea merupakan burung khas Papua dimana dari 43 spesies burung cendrawasih, 35 diantaranya ditemukan di Papua. Jenis burung ini banyak tersebar di Indonesia bagian timur terutama di Papua, Ternate, Pulau Aru, dan pulau kecil disekitarnya. Burung ini juga biasa dijumpai di Papua New Guinea, Australia dan pulau-pulau yang berdekatan dengan Papua (Wikipedia 2009).

\section{KESIMPULAN}

Berdasarkan hasil pembahasan semua variabel dapat di simpulkan bahwa di hutan sawinggrai menyimpan banyak fauna endemik yang dilihat oleh masyarakat cukup baik dan hutan sawinggrai dikatakan layak untuk dijadikan lokasi pengembangan ekowisata 
berbasis fauna endemik, oleh sebab itu dibutuhkan peran dari pemerintah guna melindung flora dan fauna yang ada di hutan tersebut.

\section{DAFTAR PUSTAKA}

Agus Purnamo. Menjaga hutan kita prokontra kebijakan moratorium hutan dan gambut. PT Gramedia. Jakarta. 2012.

Alikodra, S.M. 2002, Pengelolahan Satwa Liar, Jilit I IPB Bogor

Cochran W. G. Teknik penarikan sampel. Catatan pertama. Edisi ketiga. Universitas Indonesia. Pess. Jakarta 1991.

Dr. Chandra Dewana Boer. Orang Hutan Tersayang. Wanajadi Chakra Renjana. Yogjakarta. 2013.

Fandeli C. 2000. Pengertian dan Konsep Dasar Ekowisata. Buku Materi Kusus Pengusahaan Ekowisata Angkatan II. Yogyakarta 27 Maret, April 2010, Fakultas Kehutanan UGM.

Hadi S. Alikodra. Teknik Pengelolaan Satwa Liar Dalam Rangka. Mempertahankan Keaneka Ragaman Hayati Indonesia. IPB Press. Bogor. 2010.
Hidayati D. Mujiyani, Rachmawati L, dan Zaekani A. 2003. Ekowisata: Pembelajaran dari Kalimantan Timur. Pustaka Sinar Harapan. Pustaka Penelitian Kependudukan LIPI.

Kiroh H. J. 2006. Kajian Potensi Keanekaragaman Flora dan Fauna langka endemik dalam kaitan pengembangan ekowisata sebagai upaya pemberdayaan masyarakat dipulau Bangka Sulawesi Utara.

Kiroh H. J; Manopo J. H; Wungouw S. H; Ratulangi F. S; Rimbing S. C; Kawatu H. M; dan Assa J.V.G. 2012. Studi Tentang Respons Masyarakat Terhadap Pengembangan Ekowisata Berbasis Fauna Endemik di Gunung Tumpa. Fakultas Peternakan UNSRAT, Manado.

Nadjamudin Sugeha, Bc, Ek. Upaya Pengembangan Objek Wisata Alam di TNBNW. Edisi II. Buletin Rimbawan TNBNW. 2011.

Singarimbun dan Effendi 1995. Metolide Penelitian Survey. Lembaga Penelitian, Pendidikan dan Penerangan Ekonomi dan Sosial, Jakarta. 